\title{
Article \\ Seed Germination and Seedling Growth of Four Bedding Plants in Substrate Containing Coal Bottom Ash Mixed with Coir Dust
}

\author{
Yong-Ha Rhie ${ }^{1,+}\left(\mathbb{D}\right.$, Suyun Nam ${ }^{2,+}$ and Jongyun $\mathrm{Kim}^{3, *}$ (1) \\ 1 Department of Horticulture and Forestry, Pai Chai University, Daejeon 35345, Korea; rhie@pcu.ac.kr \\ 2 Department of Horticulture, University of Georgia, Athens, GA 30602, USA; Suyun.Nam@uga.edu \\ 3 Department of Plant Biotechnology, Korea University, Seoul 02841, Korea \\ * Correspondence: jongkim@korea.ac.kr; Tel.: +82-3290-3011 \\ + These authors contributed equally to this work.
}

Citation: Rhie, Y.-H.; Nam, S.; Kim, J. Seed Germination and Seedling Growth of Four Bedding Plants in Substrate Containing Coal Bottom Ash Mixed with Coir Dust. Agronomy 2021, 11, 1902. https://doi.org/ 10.3390/agronomy11101902

Academic Editor:

Antonios Chrysargyris

Received: 10 September 2021

Accepted: 17 September 2021

Published: 22 September 2021

Publisher's Note: MDPI stays neutral with regard to jurisdictional claims in published maps and institutional affiliations.

Copyright: (c) 2021 by the authors. Licensee MDPI, Basel, Switzerland. This article is an open access article distributed under the terms and conditions of the Creative Commons Attribution (CC BY) license (https:/ / creativecommons.org/licenses/by/ $4.0 /)$.

\begin{abstract}
Coal bottom ash (BA) is a by-product of coal-fired power generation and can be utilized as a growing substrate for ornamental plants. The physical and hydraulic properties of BA-mixed substrates (coir dust:BA, 10:0, 9:1, 8:2, 7:3, and 6:4, v/v) and commercial germinating media (BM2; Berger Peatmoss) were investigated, and the effects of the substrate mixtures on seed germination, seedling growth, and heavy metal concentrations $(\mathrm{Cd}$ and $\mathrm{Pb})$ were evaluated for four common bedding plants (periwinkle (Catharanthus roseus), globe amaranth (Gomphrena globose), impatiens (Impatiens walleriana), and petunia (Petunia multiflora)). As the BA:coir dust increased, the air space rate in the substrate increased from 25.5 to $28.0 \%$, providing the substrate with sufficient porosity. However, the container capacity and amount of easily available water decreased from 63.1 to $53.7 \%$ as BA proportions increased. In the final germination percentage and days to germination of the four bedding plants, no significant differences were detected among the substrate mixtures. Although the impatiens and petunias displayed poor growth (46-55\% and $42-56 \%$ of dry weight, respectively) in the BA-mixed substrates compared to the BM2, no apparent differences in the seedling growth of periwinkles and globe amaranths were found between 7:3 (coir dust:BA) substrate and BM2. These results indicated that the BA-mixed substrates had the potential to replace the commercial germinating media. The plants grown in the BA-mixed substrates contained Cd, but it was unlikely to be derived from the BA.
\end{abstract}

Keywords: coir dust; globe amaranth; impatiens; periwinkle; petunia; sustainable agriculture

\section{Introduction}

Although coal-fired power generation is regulated to reduce environmental pollution, it still continues to dominate as a source of global electricity generation. Coal ash, a by-product of coal-fired power generation, is discarded as waste and its quantity has increased [1]. In the USA, approximately 130 million tons of coal ash were produced in 2014 , rendering it one of the largest contributors to industrial waste [2]. Coal ash is broadly classified into fly ash and bottom ash (BA). Fly ash is a powdery fine particle with physical properties similar to those of cement, while BA can be used as a granule with a diameter of $1 \mathrm{~mm}$ or more [3].

While coal ash has been studied and commercialized for use in road construction and embankment materials [4], BA has various advantages as a substrate for plants. BA is less dense than sand and is a cheaper alternative to perlite, vermiculite, or sand, and can be used to increase substrate porosity [5]. Although organic materials such as sphagnum moss, rice hulls, and bark are susceptible to corrosion and can change the physical and chemical properties of the substrate during long-term plant cultivation [6-8], BA does not significantly change the properties of the substrate, even after long-term use, because it is an inorganic component. Coir dust is the waste material made from coconut husk and is widely used as a sphagnum peat substitute in soilless growing media for potted plant 
production [9]. Coir dust could have a similar level of water-holding capacity as sphagnum peat, and it has the advantage of being cheaper and more environmentally friendly than sphagnum peat. However, to use coir dust as a medium, perlite is added to increase air space and drainage in the substrate. In the growth of petunia and marigold, the greatest height and shoot fresh weight occurred in a substrate mixed with coir dust and perlite in an 8:2 ratio [10]. Coir dust has a low bulk density ranged from 0.04 to $0.08 \mathrm{~g} \cdot \mathrm{cm}^{-3}$ [11] and the $8: 2$ (coir dust:perlite) substrate was only $0.09 \mathrm{~g} \cdot \mathrm{cm}^{-3}$ [10], so there is a risk of falling due to external wind or impact when growing plants in pots. BA has a bulk density of $0.6 \mathrm{~g} \cdot \mathrm{cm}^{-3}$ [12] and has the advantage of providing physical support for the pots and containers while giving an air space in the coir dust-based substrate. The physical and chemical properties of BA were investigated according to the particle size, and the optimum mixing ratio between coir dust and BA and its utilization as a horticultural substrate were evaluated [12]. Although the addition of BA lowered the amounts of easily available water (EAW) and buffering water (BW) in the substrate, it increased the air space in the substrate, thus rendering it suitable for the growth of plants that require air space in the root zone. Many studies have reported that mixtures of BA and other materials, such as bark or pine wood, can be used as substrates for the cultivation of roses [13], poinsettias [14-16], and hydrangeas [17,18].

Previous studies have mainly focused on the growth of plants in substrates containing coal BA [13-18], but few studies have focused on the applicability of these substrates for the germination and seedling development stages. Unlike adult plants, root development begins in a seedling stage, so below-ground environments such as substrates have a significant effect on the growth of seedlings [19]. In the previous study, BA was used as a supplemental material in the substrates for the plants where their roots were already developed, but the effect of BA in the substrates for the germination and seedling production was not tested, where the root development of plants would be initiated. Further, using BA as a part of the substrate materials for bedding plant seedling production would have less impact on human consumption or soil contamination by potential contents of heavy metals in BA, since bedding plants are not dietary but for their aesthetic values, and their volume in the substrates for seedling substrates are small.

Incorporating BA as a part of substrate materials for seedling production may have a benefit to increase the root development of bedding plants. When maize (Zea mays) seedlings were grown in soil with various air-filled porosities, a secondary root growth increased as the air space in soil increased, and the availability of oxygen promoted secondary root initiation [20]. Also, well-drained media are suitable for all bedding plants used in the experiments, and it is recommended to be sure to allow the substrates to dry out thoroughly between irrigations to prevent root disease [21]. The substrate in which BA is mixed is suitable for the growth of bedding plants because it would improve the drainage of the media.

Therefore, we hypothesized that the addition of BA would increase the percentage of air space in the substrate and affect seedling growth of bedding plants without having a negative effect on dietary consumption. Moreover, further studies are warranted because the physical properties of substrates mixed with various proportions of coal BA, and the heavy metal contamination in plants grown using them, have not been adequately investigated. The purpose of our experiment was to investigate (1) the physical properties of each coal BA-mixed substrate and (2) the germination, seedling growth, and heavy metal content of four bedding plants grown in these coal BA-mixed substrates. We used periwinkle, globe amaranth, impatiens, and petunia as plant materials in our experiments, which are commonly used as bedding plants in Asia and the United States. Bedding plants used in this study were among the top 50 annual bedding and garden plants sales in the United States in 2019, where petunia and impatiens ranked the 1st and 5th with the annual sales values of 238 and 91 million USD, respectively [22]. 


\section{Materials and Methods}

\subsection{Substrates Characterization}

We obtained the BA from Korea Midland Power Co., Ltd. (Boryeong, Korea) on 23 February 2016, and imported coir dust (Natural Peat, EF Top, Yongin, Korea) from Sri Lanka. Before mixing the BA and coir dust substrates, the BA was sieved through a $3.0 \mathrm{~mm}$ mesh and only the BA particles that passed through the mesh were used as experimental material. The coir dust and BA were mixed at volume ratios of 10:0 (100\% coir dust), 9:1, 8:2, 7:3, and 6:4 and a commercial germinating media (BM2; Berger Peat moss, Saint-Modeste, QC, Canada) was also tested as a control.

To investigate the particle size distribution of the mixed substrates, the substrates with various ratios of coir dust and BA were oven-dried at $105^{\circ} \mathrm{C}$ for $24 \mathrm{~h}$ and $100 \mathrm{~g}$ samples were measured and used for analysis. After shaking for $30 \mathrm{~min}$ with a sieve shaker using differentsized sieves $(2.80,1.40,0.71,0.36,0.15$, and $0.106 \mathrm{~mm})$, the weight of the remaining sample in each sieve was measured.

\subsection{Physical Properties of the Substrates}

The physical properties of the substrate mixes, including air space, container capacity, and solids ratio, were determined using the NCSU porometer developed by North Carolina State University [23]. The steel cylinder was filled with the substrate as per the method described by Bilderback [24]. All pores of the substrate were then saturated with distilled water by performing bottom watering of the sample until the pores on the surface of the substrate were filled. After $15 \mathrm{~min}$, the water was drained by the action of gravity, and the drainage volume was measured. Subsequently, the wet and dry substrates were weighed. The dry weight of the substrate was measured after oven-drying the sample completely at $105^{\circ} \mathrm{C}$. The air space, container capacity, and solids ratio were then calculated using the following equations:

$$
\text { Air Space }(\%)=(\text { drainage } / \text { cylinder volume }) \times 100
$$

Container capacity $(\%)=[($ wet weight - dry weight $) /$ cylinder volume $] \times 100$

Solid $(\%)=[($ cylinder volume - air space - container capacity $) /$ cylinder volume $] \times 100$

\subsection{Hydraulic Property of Substrates}

We used a sand box (Model 0 to $10 \mathrm{kPa}$, Eijekelkamp Agrisearch Equipment, Giesbeek, the Netherlands) and defined the EAW (1.0-5.0 kPa) and BW (5.0-10.0 kPa) to investigate the retention curves of the mixed coir dust and BA substrates. The ratio of EAW to BW was calculated according to the methods reported by Milks [25] and Wallach [26].

\subsection{EC and $p H$ of Substrates}

Electrical conductivity (EC) and $\mathrm{pH}$ of the substrates mixed with coir dust and BA were measured using the saturated paste method [27]. Each substrate was saturated with distilled water for $2 \mathrm{~h}$ for reaching chemical equilibrium. The paste was passed through a filter paper and measured EC and pH by a multiparameter meter (Orion star A215, Thermo Scientific, Waltham, MA, USA).

\subsection{Seed Germination and Seedling Growth of Ornamental Plants}

Periwinkle (Catharanthus roseus 'Pacifica XP Polka Dot'), globe amaranth (Gomphrena globosa 'Buddy Purple'), impatiens (Impatiens walleriana 'Super Elfin XP Deep Pink'), and petunia (Petunia multiflora 'Damask Blue') seeds were purchased from Ball Horticultural Co., West Chicago, IL, USA, on 14 March 2016. A total of 24 treatments were conducted by combining the six substrate types and four plant species. Four replicates were considered per treatment. The seeds were sown in 128-cell trays filled with each coir dust and BA substrate mixture; every 16 cells were considered as a single treatment replicate. The seeds were sown on 23 March 2016, in an experimental glasshouse at Korea University 
in Seoul. Top watering was performed until the seeds germinated, and from 12 April, seedlings were fertigated with a 20 N-8.7 P-16.6 K water-soluble fertilizer (Multifeed; Haifa Chemicals, Haifa Bay, Israel) solution at a rate of $500 \mathrm{mg} \cdot \mathrm{L}^{-1}$. Sufficient watering and fertigation were carried out daily to prevent water stress from on the plants, following the standard practice of most practical seedling producers. The final germination percentage and the number of days to germination were recorded until 13 April. We considered the germination that the shoot or cotyledons came out through the soil. On 12 May, seedling growth variables, including the leaf number, chlorophyll content (SPAD value), and the shoot and root fresh/dry weights were measured. During the experiment, the temperature, $\mathrm{RH}$, and DLI inside the glasshouse were measured using a temperature and humidity sensor (VP-3; Decagon Devices, Pullman, WA, USA) and a photosynthetic photon flux sensor (QSO-Sun; Apogee Instruments, Logan, UT, USA) connected to a data logger (CR1000; Campbell Scientific, Logan, UT, USA). During the experiment, average daily temperature, $\mathrm{RH}$, and DLI in the glasshouse were $22 \pm 2.0^{\circ} \mathrm{C}$ (mean $\pm \mathrm{SD}$ ), $54 \pm 10.2 \%$, and $12 \pm 4.5 \mathrm{~mol} \cdot \mathrm{m}^{-2} \cdot \mathrm{d}^{-1}$, respectively.

\subsection{Heavy Metal Analysis of Plants}

The heavy metals in the plants were extracted using $\mathrm{CaCl}_{2}$ extraction [28] and measured according to the method described by the Rural Development Administration [29]. $\mathrm{Cd}$ and $\mathrm{Pb}$ were analyzed using an inductively coupled plasma-optical emission spectrometer (730 Series, Agilent, Santa Clara, CA, USA).

\subsection{Statistical Analysis}

The experimental design for the seed germination and growth experiment was a randomized complete block design $(n=4)$. The particle size distribution, physical and hydraulic properties, and EC and $\mathrm{pH}$ of the substrates and the heavy metal content of the plants were measured in triplicate for each substrate. All data were tested using analysis of variance, followed by the Fisher's least significant difference test for multiple comparisons using the SAS software (version 9.4; SAS Institute, Cary, NC, USA).

\section{Results and Discussion}

\subsection{Characteristics of Mixed Coir Dust and BA Substrates}

In the $100 \%$ coir dust and BM2 substrate, particles smaller than $1.40 \mathrm{~mm}$ occupied more than $80 \%$ of the total substrate (Figure 1 ). However, as the BA content increased, the proportion of relatively large particles $(>1.40 \mathrm{~mm})$ increased. The addition of BA increased the proportion of larger particles, particularly those with sizes ranging between 1.40 and $2.80 \mathrm{~mm}$, which, in the $6: 4$ (coir dust:BA) substrate, consisted of more than $60 \%$ of the sample. In the BM2, the air space, container capacity, and solids ratios were $12 \%$, $77 \%$, and $12 \%$, respectively (Table 1). All mixed coir dust and BA substrates had lower container capacities than that observed in the BM2. The container capacities of the 10:0, 9:1, $8: 2,7: 3$, and $6: 4$ (coir dust:BA) samples were $63 \%, 61 \%, 58 \%, 54 \%$, and $53 \%$, respectively. The porosity characteristics, such as the air space and container capacity, of horticultural substrates, depend on the size of the coal ash. Silt-sized particles of coal ash are known as fly ash, and their addition to the substrate reduces the air spaces in the substrate [12]. However, most of the BA particles used in this experiment were relatively large (sizes ranging between 1.40 and $2.80 \mathrm{~mm}$; Figure 1). Therefore, as the proportion of BA increased, the container capacity decreased but the percentage of solid matter increased (Table 1). Owing to these BA characteristics, the air space ratios of the BA-mixed substrates were higher than those of the commercial germinating substrate BM2, and none of the mixed substrates reached the container capacity of the BM2 (Table 1). 


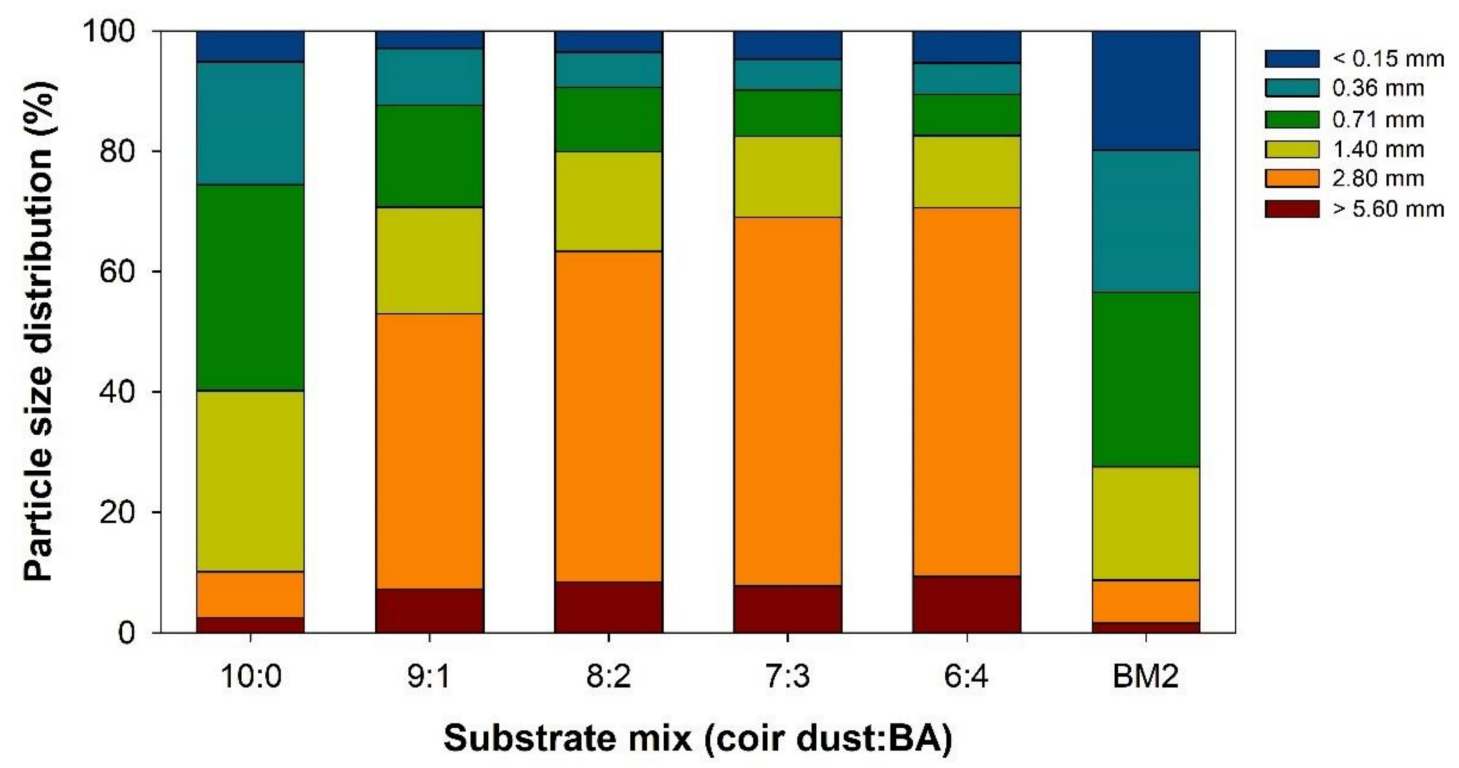

Figure 1. Particle size distributions in mixed coir dust and coal bottom ash (BA) substrates, and in a commercial germinating mixture BM2.

Table 1. Percentages of air space, container capacity, and solid matter in mixed coir dust and coal bottom ash (BA) substrates and in a commercial germinating mixture BM2.

\begin{tabular}{|c|c|c|c|c|c|c|c|c|}
\hline \multirow{2}{*}{$\begin{array}{c}\begin{array}{c}\text { Substrates } \\
\text { (Coir Dust:BA) }\end{array} \\
10: 0\end{array}$} & \multicolumn{2}{|c|}{$\begin{array}{l}\text { Air Space } \\
(\%)\end{array}$} & \multicolumn{2}{|c|}{$\begin{array}{c}\text { Container Capacity } \\
(\%)\end{array}$} & \multicolumn{2}{|c|}{$\begin{array}{l}\text { Solid } \\
(\%)\end{array}$} & \multicolumn{2}{|c|}{$\begin{array}{l}\text { Bulk Density } \\
\left(\mathrm{g} \cdot \mathrm{cm}^{-3}\right)\end{array}$} \\
\hline & $25.5 \pm 2.21$ & $b$ & $63.2 \pm 1.82$ & $\mathrm{~b}$ & $11.4 \pm 0.84$ & c & $0.06 \pm 0.001$ & $\mathrm{f}$ \\
\hline $9: 1$ & $26.5 \pm 0.78$ & $a b$ & $61.1 \pm 1.07$ & $\mathrm{~b}$ & $12.4 \pm 0.54$ & c & $0.12 \pm 0.001$ & $\mathrm{~d}$ \\
\hline $8: 2$ & $26.2 \pm 1.64$ & $a b$ & $58.6 \pm 1.36$ & c & $15.3 \pm 0.78$ & $\mathrm{~b}$ & $0.16 \pm 0.003$ & c \\
\hline $7: 3$ & $28.0 \pm 0.74$ & $\mathrm{a}$ & $54.9 \pm 1.84$ & $\mathrm{~d}$ & $17.0 \pm 1.18$ & $a b$ & $0.21 \pm 0.004$ & $\mathrm{~b}$ \\
\hline $6: 4$ & $27.7 \pm 0.95$ & $a b$ & $53.7 \pm 0.18$ & $\mathrm{~d}$ & $18.5 \pm 0.99$ & $\mathrm{a}$ & $0.25 \pm 0.003$ & a \\
\hline BM2 & $11.7 \pm 1.33$ & $c$ & $76.6 \pm 0.94$ & $\mathrm{a}$ & $11.7 \pm 2.25$ & c & $0.10 \pm 0.001$ & $\mathrm{e}$ \\
\hline Significance & \multicolumn{2}{|c|}{$* * *$} & \multicolumn{2}{|c|}{$* * *$} & \multicolumn{2}{|c|}{$* * *$} & \multicolumn{2}{|c|}{$* * *$} \\
\hline
\end{tabular}

Mean \pm SD. Mean values with the same letter are not significantly different $(p \leq 0.05)$, as per results based on the Fisher's least significant difference test $(n=3) .{ }^{* * *}$, significant at $p \leq 0.001$ after ANOVA.

In the BM2, there was approximately $0.29 \mathrm{~m}^{3} \cdot \mathrm{m}^{-3}$ EAW $\left(0.33-0.62 \mathrm{~m}^{3} \cdot \mathrm{m}^{-3}\right)$, which was higher than that of the coir dust and BA mixtures (Figure 2). The EAW in the 10:0, 9:1, $8: 2,7: 3$, and $6: 4$ mixed substrates were $0.20,0.19,0.18,0.13$, and $0.11 \mathrm{~m}^{3} \cdot \mathrm{m}^{-3}$, respectively, thereby suggesting a decrease in EAW with an increasing BA portion. The substrates with higher proportions of BA had lower EAW values than the BM2 (Figure 2) and indicated the necessity of conducting more careful water management than the commercial horticultural substrate. However, in this experiment, top watering and fertigation was performed daily, and thus, there was no case of severe water shortage. Furthermore, provision of sufficient air space in the substrate may have a positive effect on the germination and seedling growth of certain species. Previous research reported that the seed germination and biomass (shoot and root dry weights) of asparagus were high in substrates with a high air space ratio [30]. Similarly, the growth of tomato seedlings decreased in potting mixtures containing $100 \%$ pig manure vermicompost, because of the poor porosity and aeration of the substrate [31]. Seed germination requires sufficient aeration because the process involves oxygen for respiration during the germination process. Thus, provision of good aeration with BA as a substitute for perlite may enhance germination and seedling quality. 




Figure 2. Water retention curve in mixed coir dust and coal bottom ash (BA) substrates and in a commercial germinating mixture BM2.

The EC of coir dust 100\%, 9:1, 8:2, 7:3, 6:4 (coir dust:BA), and BM2 were $0.85,0.69,0.63$, $0.60,0.57$, and $0.87 \mathrm{dS} \cdot \mathrm{m}^{-1}$, respectively, but there were no significant differences among substrates (Table 2). Coal ash is a by-product of coal-fired power generation, and it can contain plant nutrients such as $\mathrm{Ca}, \mathrm{Mg}, \mathrm{S}$, and $\mathrm{B}$, which are necessary for plant growth [32]. However, we found no significant differences among substrates in EC, indicating that it was difficult to judge that BA played a role in providing specific elements. Coir dust was the main cause of increasing the EC of the substrate and the EC was the highest at $0.85 \mathrm{dS} \cdot \mathrm{m}^{-1}$ in coir dust $100 \%$ (Table 2). Depending on the coir dust source, the EC of coir dust ranged from 0.3 to $2.9 \mathrm{dS} \cdot \mathrm{m}^{-1}$ [11] and varied from 0.39 to $5.97 \mathrm{dS} \cdot \mathrm{m}^{-1}$ [33]. The coir dust contained a high level of potassium, sodium, and chloride, which increased the EC, and possibly because coconut cultivation managers fertilized with $\mathrm{KCl}$ or $\mathrm{NaCl}$ [11]. Although these excess soluble salts of coir dust could be easily and effectively leached through customary irrigation, when growing salt-sensitive plants, the grower's attention is required to use coir dust as a substrate [33]. When the EC of the media extracted through the saturation extract method was in the range of $0.75-1.99 \mathrm{dS} \cdot \mathrm{m}^{-1}$, it was suitable for seedlings and salt-sensitive plants [34]. Because the EC range of the substrates used in this experiment was 0.3 to $0.85 \mathrm{dS} \cdot \mathrm{m}^{-1}$ (Table 2), they were not probably problematic in germinating and seeding growth in our experiment.

The carbon/nitrogen $(\mathrm{C} / \mathrm{N})$ ratio of coir dust was known to be high because of low water-soluble nitrogen content. The $\mathrm{C} / \mathrm{N}$ ratio of coir dust ranged from 75 to 186 depending on the source and was higher than that of commercial sphagnum peat [33]. This high $\mathrm{C} / \mathrm{N}$ ratio could inhibit the mobility of soluble nitrogen when coir dust was used as substrate for plants. However, most of the carbon components of coir dust were lignin and cellulose, which were difficult to degrade by microorganisms [33]. Moreover, the slight nitrogen deficit when coir dust was used as a substrate could be overcome through applying conventional fertilization [35]. We applied daily fertigation after seed germination to supply nitrogen to the seedlings, and nitrogen might be available for the seedlings. More precisely, the nitrogen content in plant tissue should be quantified, but in this study, the nitrogen content could not be measured. 
Table 2. Electric conductivity and $\mathrm{pH}$ in substrates mixed with coir dust and coal bottom ash (BA) and commercial germinating mixture BM2.

\begin{tabular}{ccc}
\hline $\begin{array}{c}\text { Substrates } \\
\text { (Coir Dust:BA) }\end{array}$ & $\begin{array}{c}\text { EC } \\
\left(\mathbf{d S} \cdot \mathbf{m}^{-\mathbf{1}} \mathbf{)}\right.\end{array}$ & pH \\
\hline $10: 0$ & $0.85 \pm 0.168$ & $4.59 \pm 0.420$ \\
$9: 1$ & $0.69 \pm 0.068$ & $4.82 \pm 0.287$ \\
$8: 2$ & $0.63 \pm 0.110$ & $4.88 \pm 0.167$ \\
$7: 3$ & $0.60 \pm 0.095$ & $4.92 \pm 0.099$ \\
$6: 4$ & $0.57 \pm 0.061$ & $4.86 \pm 0.159$ \\
BM2 & $0.87 \pm 0.199$ & $5.36 \pm 0.236$ \\
\hline Significance & NS & NS
\end{tabular}

\subsection{Seed Germination}

There were no significant differences in the final germination percentage $(p \leq 0.05)$ of each species among the substrates (Table 3 ). The final germination percentages of the periwinkles, globe amaranths, impatiens, and petunias were approximately $61-80 \%$, $75-92 \%, 95-100 \%$, and $77-92 \%$, respectively. The days to germination of the periwinkles, globe amaranths, impatiens, and petunias were approximately 4, 7, 12, and 10 days, respectively, and there were also no significant differences among the different substrates. This was because seed germination occurred within a short 2-week period in this experiment and was mainly determined by the innate characteristics of seeds, thus indicating that the physical properties of substrates did not exert a significant effect on this parameter. Similar results were found in a previous study, which showed differences in asparagus seedling growth in substrates with various physical properties, but not in the final germination percentage [30].

Table 3. The final germination percentages and days to germination of four bedding plants (Catharanthus roseus, Gomphrena globosa, Impatiens walleriana, and Petunia multiflora) sown in mixed coir dust and coal bottom ash (BA) substrates and in a commercial germinating mixture BM2.

\begin{tabular}{|c|c|c|c|c|c|c|c|c|}
\hline \multirow{2}{*}{$\begin{array}{c}\text { Substrates } \\
\text { (Coir Dust:BA) }\end{array}$} & \multicolumn{4}{|c|}{ Germination Rate (\%) } & \multicolumn{4}{|c|}{ Days to Germination } \\
\hline & C. roseus & G. globosa & I. walleriana & P. multiflora & C. roseus & G.globosa & I. walleriana & P. multiflora \\
\hline 10:0 & $77 \pm 4.7$ & $75 \pm 10.2$ & $97 \pm 1.8$ & $77 \pm 4.7$ & $15 \pm 0.3$ & $7 \pm 0.3$ & $12 \pm 0.2$ & $9 \pm 0.3$ \\
\hline $9: 1$ & $61 \pm 9.0$ & $95 \pm 3.0$ & $100 \pm 0.0$ & $91 \pm 9.0$ & $14 \pm 0.3$ & $7 \pm 0.3$ & $13 \pm 0.2$ & $9 \pm 0.2$ \\
\hline $8: 2$ & $66 \pm 5.4$ & $88 \pm 7.7$ & $95 \pm 1.6$ & $92 \pm 5.4$ & $15 \pm 0.4$ & $7 \pm 0.3$ & $12 \pm 0.2$ & $9 \pm 0.2$ \\
\hline $7: 3$ & $75 \pm 2.6$ & $89 \pm 3.9$ & $98 \pm 1.6$ & $84 \pm 2.6$ & $15 \pm 0.3$ & $7 \pm 0.3$ & $12 \pm 0.2$ & $9 \pm 0.2$ \\
\hline $6: 4$ & $80 \pm 8.2$ & $86 \pm 6.4$ & $97 \pm 1.8$ & $88 \pm 8.2$ & $15 \pm 0.3$ & $7 \pm 0.3$ & $12 \pm 0.2$ & $9 \pm 0.2$ \\
\hline BM2 & $77 \pm 4.7$ & $92 \pm 3.9$ & $100 \pm 0.0$ & $88 \pm 4.7$ & $15 \pm 0.3$ & $8 \pm 0.3$ & $11 \pm 0.2$ & $10 \pm 0.5$ \\
\hline Significance & NS & NS & NS & NS & NS & NS & NS & NS \\
\hline
\end{tabular}

Mean \pm SE. NS, not significant at $p \leq 0.05$ after ANOVA.

\subsection{Seedling Growth}

\subsubsection{Periwinkles}

Although the leaf number and root dry weight of the periwinkle seedlings did not differ across the substrates, the plant height, total chlorophyll content (SPAD units), leaf area, and shoot dry weight in the 10:0, 9:1, and 8:2 (coir dust:BA) substrates were significantly lower than those in BM2 (Table 4). However, the seedlings grown in the 7:3 and 6:4 mixed substrates showed similar plant heights and leaf areas to those grown in BM2. Furthermore, the shoot and total dry weights were similar between the 6:4 and BM2 substrates. This is likely because the mixed substrates with relatively high BA content would provide better aeration, thus enhancing periwinkle seedling growth. 
Table 4. The growth parameters of the four bedding plants grown for 7 weeks in mixed coir dust and coal bottom ash (BA) substrates and in a commercial germinating mixture BM2.

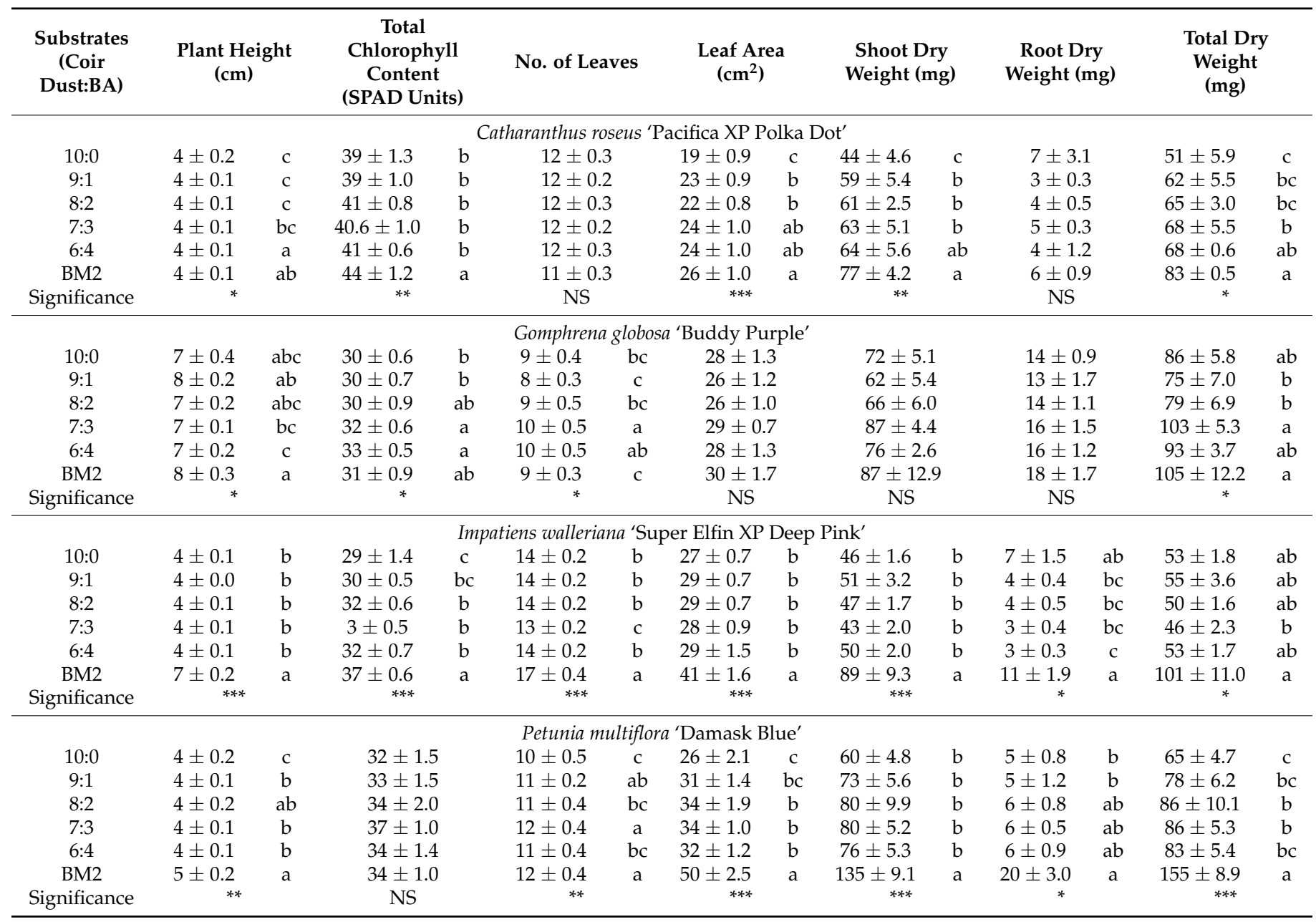

Mean \pm SE. Mean values with the same letter are not significantly different $(p<0.05)$, as per results based on the Fisher's least significant difference test $(n=4)$. NS, not significant; ${ }^{*}{ }^{* *},{ }^{* * *}$, significant at $p \leq 0.05,0.01$, or 0.001 , respectively.

\subsubsection{Globe Amaranth}

There were no significant differences in the leaf area, shoot dry weight, or root dry weight of the globe amaranth seedlings between any of the substrates (Table 4). In contrast to the periwinkle seedling results, application of the 6:4 mixed substrate showed the lowest plant height. Although there were significant differences in plant height, SPAD value, and total dry weight, the plants did not show any unique trends. Among the mixed substrates, the seedlings grown using the 7:3 substrate, which had a relatively high BA content, showed a similar dry weight to the BM2 seedlings, and this mixture is therefore considered a suitable BA-mixed substrate for global amaranth seedling growth.

\subsubsection{Impatiens}

The growth parameters of the impatiens seedlings grown in BM2 were higher than those of any of the mixed substrates (Table 4). The number of leaves and leaf area of the impatiens seedlings in the BM2 were approximately $27 \%$ and $43 \%$ higher than those of the substrates containing coir dust and BA. Furthermore, the shoot dry weight, root dry weight, and total dry weight of impatiens seedlings grown in the coir dust and BA mixtures were reduced by $48 \%, 63 \%$, and $47 \%$, respectively, compared to the seedlings grown in BM2, suggesting that the mixed coir dust and BA substrate might not be suitable for impatiens. 


\subsubsection{Petunia}

The petunia seedlings grown in BM2 had the highest plant height, number of leaves, and leaf area among all the treatments (Table 4). The shoot dry weight, root dry weight, and total dry weight of the seedlings grown in BM2 were approximately double those of the seedlings grown in the mixed coir dust and BA substrates, regardless of the mixing ratio. Likewise, petunia seedling growth in the mixed coir dust and BA substrates was not comparable to that of seedling grown in the commercial propagation substrate.

\subsubsection{Seedling Growth Comparisons among the Four Bedding Plants}

Depending on the plant species, the capacity of the mixed coir dust and BA substrates to replace the commercial substrate BM2 in seedling production differed. For periwinkles and globe amaranths, seedling growth in the mixed coir dust and BA substrates at a 7:3 or 6:4 ratio was similar to that in BM2. However, the 10:0, 9:1, and 8:2 mixed substrates, which had relatively low BA content, reduced seedling growth compared to the 7:3 and 6:4 mixed substrates. This might be because the proportion of the air space increased when BA was added (Table 1) and increasing the air space ratio in the substrate was favorable for periwinkle and globe amaranth seedling growth.

However, these results are contrary to those reported by a few previous reports. For example, geraniums, marigolds, and petunias grown in substrates with lower air space ratios and higher container capacities had greater shoot fresh weights than those grown in substrates with higher air space ratios and lower container capacities [10]. Tilt [36] also showed that, in several landscape species, shoot growth increased with increasing substrate container capacity. These conflicting results were assumed to have been affected not only by the physical properties of the substrates but also by the irrigation method used. In insufficiently watered experimental conditions, plants grow better in a substrate with a high container capacity. However, high container capacity does not always promote plant growth. If the water supply is sufficient, the pores become filled with water, hindering plant root respiration. Plant root respiration provides energy for root growth and maintenance, ion absorption, and the transportation of nutrients to the xylem [37]. Oxygen deficiencies in the root zone are limiting to several important cellular physiological processes, including the biosynthesis of heme, sterol, and fatty acids, and cause high energy consumption to increase the anaerobic generation of ATP by cytosolic glycolysis $[37,38]$. This negatively affects plant growth. Woodard [13] reported that there was a decrease in the diameter of marigold flowers grown in rock wool, which has a container capacity $27 \%$ higher than that of coal BA. In our experiment, abundant top watering was performed daily and we considered that there was no water deficit.

In contrast to the periwinkles and globe amaranths, the quality of the impatiens and petunia seedlings produced in the mixed coir dust and BA substrates was inferior to those grown in BM2 (Table 4), and this might not be attributed to the physical properties of the substrates alone. Although BM2 is mainly composed of peat moss and perlite, it also contains seedling fertilizers such as nitrogen, phosphorus, potassium, and other trace minerals. Thus, BM2 might have provided better conditions for impatiens and petunia seedling growth than the mixed coir dust and BA substrates, which might not have contained enough nutrients for those species. To commercialize the mixed coir dust and BA substrates, appropriate nutrient incorporation should be considered.

\subsection{Heavy Metals in Plants}

Although the species used in the present experiment were ornamental bedding plants, we tested their heavy metal content to determine the detrimental effect of BA on heavy metal accumulation in the plants. Based on the 'Maximum levels for certain contaminants in foodstuffs' set by the European Union, the heavy metal content recommendations for leaf vegetables are $0.2 \mathrm{mg} \cdot \mathrm{kg}^{-1}$ or less of $\mathrm{Cd}$ and $0.3 \mathrm{mg} \cdot \mathrm{kg}^{-1} \mathrm{of} \mathrm{Pb}$ [39]. The $\mathrm{Pb}$ accumulated in the periwinkles, globe amaranths, impatiens, and petunias was either not detected or was below $0.3 \mathrm{mg} \cdot \mathrm{kg}^{-1}$ (Table 5). However, more than $0.2 \mathrm{mg} \cdot \mathrm{kg}^{-1} \mathrm{Cd}$ was detected in 
the globe amaranths, impatiens, and petunias. The recommended amount of $\mathrm{Cd}$ was exceeded in the globe amaranths grown in the 10:0 $\left(0.4 \mathrm{mg} \cdot \mathrm{kg}^{-1}\right), 8: 2\left(0.3 \mathrm{mg} \cdot \mathrm{kg}^{-1}\right), 7: 3$ $\left(0.3 \mathrm{mg} \cdot \mathrm{kg}^{-1}\right)$, and $6: 4\left(0.2 \mathrm{mg} \cdot \mathrm{kg}^{-1}\right)$ mixed substrates; in the impatiens grown in the 10:0 $\left(1.3 \mathrm{mg} \cdot \mathrm{kg}^{-1}\right), 9: 1\left(1.1 \mathrm{mg} \cdot \mathrm{kg}^{-1}\right), 8: 2\left(1.3 \mathrm{mg} \cdot \mathrm{kg}^{-1}\right), 7: 3\left(0.9 \mathrm{mg} \cdot \mathrm{kg}^{-1}\right)$, and $6: 4\left(0.7 \mathrm{mg} \cdot \mathrm{kg}^{-1}\right)$ mixed substrates; and in the petunias grown in the $10: 0\left(0.6 \mathrm{mg} \cdot \mathrm{kg}^{-1}\right), 9: 1\left(0.2 \mathrm{mg} \cdot \mathrm{kg}^{-1}\right)$, and $8: 2\left(0.4 \mathrm{mg} \cdot \mathrm{kg}^{-1}\right)$ mixed substrates. Since the amount of heavy metals in the substrates mixed with coir dust and BA was not measured in this study, we could not confirm how the $\mathrm{Cd}$ detected in the plants was transferred from the substrate. In other studies, some heavy metals were detected in the substrate used for plant production depending on the substrate type. When composted herb residues were mixed, approximately $4 \mathrm{mg} \cdot \mathrm{kg}^{-1}$ of $\mathrm{Cd}$ were also detected [40]. We assumed that the coir dust used in our experiment contains some $\mathrm{Cd}$ and that it could be transferred to plants, but additional research is needed to prove this. However, what was interesting about our results was that the amount of $\mathrm{Cd}$ detected in plants in impatiens was the highest at $1 \mathrm{mg} \cdot \mathrm{kg}^{-1}, 2 \sim 4$ times higher than that of other plant species (Table 5). Impatiens was known as a hyperaccumulator of heavy metal and has a better ability to absorb heavy metals than petunia [41]. Our study supports the study that plant species have different capacities to absorb heavy metals.

Table 5. The heavy metal contents in four bedding plants (Catharanthus roseus, Gomphrena globosa, Impatiens walleriana, Petunia multiflora) seedlings grown for 7 weeks in substrates mixed with coir dust and coal bottom ash (BA) and commercial germinating mixture BM2.

\begin{tabular}{|c|c|c|c|c|c|c|c|c|}
\hline \multirow{2}{*}{$\begin{array}{l}\text { Substrates } \\
\text { (Coir Dust:BA) }\end{array}$} & \multicolumn{4}{|c|}{ Cadmium (mg $\left.\cdot \mathrm{kg}^{-1}\right)$} & \multicolumn{4}{|c|}{ Lead (mg.kg $\left.{ }^{-1}\right)$} \\
\hline & C. roseus & G. globosa & I. walleriana & P. multiflora & C. roseus & G. globosa & I. walleriana & P. multiflora \\
\hline 10:0 & $0.2 \pm 0.01 \mathrm{a}$ & $0.4 \pm 0.07$ & $1.3 \pm 0.40 \mathrm{a}$ & $0.6 \pm 0.02 \mathrm{a}$ & - & - & - & - \\
\hline $9: 1$ & $0.1 \pm 0.02 \mathrm{~b}$ & $0.1 \pm 0.01$ & $1.1 \pm 0.06 \mathrm{ab}$ & $0.2 \pm 0.02 c$ & - & - & - & - \\
\hline $8: 2$ & $0.1 \pm 0.02 b$ & $0.3 \pm 0.10$ & $1.3 \pm 0.04 \mathrm{a}$ & $0.4 \pm 0.05 b$ & - & - & - & $0.2 \pm 0.10$ \\
\hline $7: 3$ & $0.0 \pm 0.01 c$ & $0.3 \pm 0.03$ & $0.9 \pm 0.04 \mathrm{ab}$ & $0.1 \pm 0.05 \mathrm{~d}$ & - & - & - & - \\
\hline $6: 4$ & - & $0.2 \pm 0.07$ & $0.7 \pm 0.01 \mathrm{ab}$ & $0.0 \pm 0.03 \mathrm{~d}$ & - & - & $0.0 \pm 0.01$ & - \\
\hline $\mathrm{BM} 2$ & - & - & $0.1 \pm 0.02 \mathrm{~b}$ & $0.1 \pm 0.02 \mathrm{~d}$ & - & - & $0.1 \pm 0.04$ & - \\
\hline Significance & $* * *$ & NS & * & $* * *$ & & & NS & \\
\hline
\end{tabular}

Mean \pm SE. Means with the same letter are not significantly different $(p<0.05)$ using Fisher's least significant difference $($ LSD) test $(n=3)$. NS, not significant; ${ }^{*}{ }^{* * *}$, significant at $p \leq 0.05$, or 0.001 , respectively.

However, it was difficult to determine whether this heavy metal contamination originated from the BA because $\mathrm{Cd}$ was also detected in some of the seedlings grown in substrates with a relatively low BA ratio and in BM2. Coal ash is known to be capable of absorbing heavy metals. Coal fly ash, which has a smaller particle size than BA, is a good absorbent material for removing $\mathrm{Pb}, \mathrm{Zn}$, and $\mathrm{Cd}$ [42]. Although the ability of plants to absorb heavy metals is a species-specific characteristic, the $\mathrm{Pb}$ content of the plants grown in the 7:3 and 6:4 (coir dust:BA) substrates, which contained relatively high BA concentrations, was lower than that of plants grown in 100\% coir dust (Table 5). Furthermore, as the recommended amounts of $\mathrm{Cd}$ and $\mathrm{Pb}$ were based on leafy vegetables and ornamental plants are not used for food, application of BA for the growth of ornamental plants may pose a few challenges.

\section{Conclusions}

This study suggests that BA can potentially be used for the seedling production of bedding plants. As BA consists of large particles, it can be used as a substrate to replace perlite. A mixture of coir dust and BA at a ratio of 7:3 was found to be favorable for growing periwinkle and globe amaranth seedlings. However, it should be considered that this optimal ratio may vary depending on the irrigation method. The effect of heavy metals from the coal BA accumulating in the plants was insignificant. The use of BA is expected not only to save substrate material costs, but also to reduce the burden on the environment, as the by-products of coal-fired power generation are reused. However, since there may be 
a negative environmental impact when using BA as a substrate, a long-term environmental assessment should also be investigated further.

Author Contributions: Conceptualization, Y.-H.R. and J.K.; methodology, Y.-H.R. and J.K.; validation, Y.-H.R., S.N., and J.K.; formal analysis, Y.-H.R. and S.N.; investigation, Y.-H.R. and S.N.; resources, J.K.; writing-original draft preparation, Y.-H.R. and S.N.; writing-review and editing, J.K.; supervision, J.K.; funding acquisition, J.K. All authors have read and agreed to the published version of the manuscript.

Funding: This research was funded by a Korea University grant, and the Korea Institute of Energy Technology Evaluation and Planning under the Ministry of Trade, Industry \& Energy of the Republic of Korea (grant number 20142020103570).

Institutional Review Board Statement: Not applicable.

Informed Consent Statement: Not applicable.

Data Availability Statement: The data presented in this study are available on request from the corresponding author.

Conflicts of Interest: The authors declare no conflict of interest. The funders had no role in the study design; in the collection, analyses, or interpretation of data; in the writing of the manuscript; or in the decision to publish the results.

\section{References}

1. World Energy Outlook. 2020. Available online: https://www.iea.org/reports/world-energy-outlook-2020 (accessed on 12 March 2021).

2. USEPA (United States Environmental Protection Agency). Coal Ash Basics. Available online: https://www.epa.gov/coalash/ coal-ash-basics (accessed on 13 March 2020).

3. Cary, E.E.; Gilbert, M.; Bache, C.A.; Gutenmann, W.H.; Lisk, D.J. Elemental composition of potted vegetables and millet grown on hard coal bottom ash-amended soil. Bull. Environ. Contam. Toxicol. 1983, 31, 418-423. [CrossRef] [PubMed]

4. Bruder-Hubscher, V.; Lagarde, F.; Leroy, M.; Coughanowr, C.; Enguehard, F. Utilisation of bottom ash in road construction: Evaluation of the environmental impact. Waste Manag. Res. 2001, 19, 545-556. [CrossRef]

5. Schlossberg, M.J.; Miller, W.P. Coal combustion by-product (CCB) utilization in turfgrass sod production. HortScience 2004, 39, 408-414. [CrossRef]

6. Evans, M.R.; Buck, J.S.; Sambo, P. The $\mathrm{pH}$, electrical conductivity, and primary macronutrient concentration of sphagnum peat and ground parboiled fresh rice hull substrates over time in a greenhouse environment. HortTechnology 2011, 21, 103-108. [CrossRef]

7. Jackson, B.E.; Wright, R.D.; Browder, J.F.; Harris, J.R.; Niemiera, A.X. Effect of fertilizer rate on growth of azalea and holly in pine bark and pine tree substrates. HortScience 2008, 43, 1561-1568. [CrossRef]

8. Jackson, B.E.; Wright, R.D.; Seiler, J.R. Changes in chemical and physical properties of pine tree substrate and pine bark during long-term nursery crop production. HortScience 2009, 44, 791-799. [CrossRef]

9. Abad, M.; Fornes, F.; Carrión, C.; Noguera, V.; Noguera, P.; Maquieira, Á.; Puchades, R. Physical properties of various coconut coir dusts compared to peat. HortScience 2005, 40, 2138-2144. [CrossRef]

10. Evans, M.R.; Stamps, R.H. Growth of bedding plants in sphagnum peat and coir dust-based substrates. J. Environ. Hortic. 1996, 14, 187-190. [CrossRef]

11. Evans, M.R.; Konduru, S.; Stamps, R.H. Source variation in physical and chemical properties of coconut coir dust. HortScience 1996, 31, 965-967. [CrossRef]

12. Rhie, Y.H.; Kang, S.; Choi, J.M.; Kim, J. Physical and chemical properties of bottom ash and coir dust mix used as horticultural substrates. Hortic. Sci. Technol. 2018, 36, 161-171.

13. Woodard, M.; Bearce, B.; Cluskey, S.; Townsend, E. Coal bottom ash and pine wood peelings as root substrates in a circulating nutriculture system. HortScience 1993, 28, 636-638. [CrossRef]

14. Engstrom, K.B.; Myers, S.G.; Bearce, B.C. Growth and flowering responses of 'Dark Red Hegg' poinsettias in coal ash-amended root media to 3 nutrient solutions in a closed-loop nutriculture system. HortScience 1994, 29, 452. [CrossRef]

15. Myers, S.S.; Bearce, B. Growth and flowering response of 'Brilliant Diamond' poinsettias in a peat vermiculite mix amended with coal bottom ash. HortScience 1993, 28, 256. [CrossRef]

16. Pitchay, D.S.; Bearce, B. Chemical and physical properties of coal bottom ash-based root media and their effect on poinsettia nutritive status, growth, and flowering. HortScience 1996, 31, 912. [CrossRef]

17. Pitchay, D.S.; Myers, S.; Bearce, B.C. Dry weight partitioning among roots, shoot bottoms and tops, and leaves of Hydrangea macrophylla cuttings rooted in coal bottom ash or peat: Perlite media containing four levels of dolomitic limestone. HortScience 1998, 33, 465. [CrossRef] 
18. Pitchay, D.S.; Sherratt, M.D.; Bearce, B.C. Inflorescence color manipulation in hydrangea forced in media containing coal bottom ash and mine soil. HortScience 1996, 31, 658. [CrossRef]

19. Kafkafi, U. Functions of the root system. In Soilless Culture; Elsevier BV: Alpharetta, GA, USA, 2008 ; pp. 13-40.

20. Liang, J.; Zhang, J.; Wong, M.H. Effects of air-filled soil porosity and aeration on the initiation and growth of secondary roots of maize (Zea mays). Plant Soil 1996, 186, 245-254. [CrossRef]

21. Ball Seed Company. Available online: https://www.ballseed.com/quickculture/ProductionGuides (accessed on 18 March 2021).

22. USDA (United States Department of Agriculture). Available online: https://www.nass.usda.gov/Publications / AgCensus/2017 (accessed on 18 March 2021).

23. Fonteno, W.; Hardin, C.; Brewster, J. Procedures for Determining Physical Properties of Horticultural Substrates Using the NCSU Porometer; Horticultural Substrates Laboratory, North Carolina State University: Raleigh, NC, USA, 1995.

24. Bilderback, T.E.; Fonteno, W.C.; Johnson, D.R. Physical properties of media composed of peanut hulls, pine bark, and peatmoss and their effects on azalea growth. J. Am. Soc. Hortic. Sci. 1982, 107, 522-525.

25. Milks, R.R.; Fonteno, W.C.; Larson, R.A. Hydrology of horticultural substrates. II. Predicting physical properties of media in containers. J. Am. Soc. Hortic. Sci. 1989, 114, 53-56.

26. Wallach, R.; Da Silva, F.; Chen, Y. Unsaturated hydraulic characteristics of composted agricultural wastes, tuff, and their mixtures. Soil Sci. 1992, 153, 434-441. [CrossRef]

27. Warncke, D. Analyzing greenhouse growth media by the saturation extraction method. HortScience 1986, 21, $223-225$.

28. Novozamsky, I.; Lexmond, T.M.; Houba, V. A single extraction procedure of soil for evaluation of uptake of some heavy metals by plants. Int. J. Environ. Anal. Chem. 1993, 51, 47-58. [CrossRef]

29. RDA (Rural Development Administration). Standard of Research Methods and Analysis for Agricultural Science; Rural Development Administration: Jeonju, Korea, 2012.

30. Li, Q.; Chen, J.; Caldwell, R.D.; Deng, M. Cowpeat as a substitute for peat in container substrates for foliage plant propagation. HortTechnology 2009, 19, 340-345. [CrossRef]

31. Atiyeh, R.M.; Edwards, C.A.; Subler, S.; Metzger, J.D. Pig manure vermicompost as a component of a horticultural bedding plant medium: Effects on physicochemical properties and plant growth. Bioresour. Technol. 2001, 78, 11-20. [CrossRef]

32. Terman, G.L.; Kilmer, V.J.; Hunt, C.M.; Buchanan, W. Fluidized bed boiler waste as a source of nutrients and lime. J. Environ. Qual. 1978, 7, 147-150. [CrossRef]

33. Abad, M.; Noguera, P.; Puchades, R.; Maquieira, A.; Noguera, V. Physico-chemical and chemical properties of some coconut coir dusts for use as a peat substitute for containerised ornamental plants. Bioresour. Technol. 2002, 82, 241-245. [CrossRef]

34. Warncke, D.D.; Krauskopf, D. Ball Redbook: Greenhouse Growth Media: Testing E Nutrition Guidelines, 15th ed.; Ball, G.J., Ed.; Ball Publishing: West Chicago, IL, USA, 1991; Volume 1, pp. 245-255.

35. Noguera, P.; Abad, M.; Noguera, V.; Puchades, R.; Maquieira, A. Coconut coir waste, a new and viable ecologically-friendly peat substitute. Acta Hortic. 2000, 517, 279-286. [CrossRef]

36. Tilt, K.M.; Bilderback, T.E.; Fonteno, W.C. Particle size and container size effects on growth of three ornamental species. J. Amer. Soc. Hortic. Sci. 1987, 112, 981-984.

37. Ben-Noah, I.; Friedman, S.P. Review and evaluation of root respiration and of natural and agricultural processes of soil aeration. Vadose Zone J. 2018, 17, 1-47. [CrossRef]

38. Bailey-Serres, J.; Voesenek, L.A.C.J. Flooding stress: Acclimations and genetic diversity. Ann. Rev. Plant Biol. 2008, 59, 313-339. [CrossRef]

39. EUR-Lex. Commission Regulation (EC) No 1881/2006. Available online: https://eur-lex.europa.eu/legal-content/EN/TXT/ ?uri=uriserv\%3AOJ.L_.2006.364.01.0005.01.ENG (accessed on 15 November 2020).

40. Zhang, J.H.; Tian, G.M.; Zhou, G.D.; He, M.M.; Wang, F.; Yao, J.H. Evaluation of organic solid wastes composts as peat substitutes for seedling production. J. Plant Nutr. 2013, 36, 1780-1794. [CrossRef]

41. Khan, A.H.A.; Kiyani, A.; Mirza, C.R.; Butt, T.A.; Barros, R.; Ali, B.; Iqbal, M.; Yousaf, S. Ornamental plants for the phytoremediation of heavy metals: Present knowledge and future perspectives. Environ. Res. 2021, 195, 110780. [CrossRef] [PubMed]

42. Gianoncelli, A.; Zacco, A.; Struis, R.P.W.J.; Borgese, L.; Depero, L.E.; Bontempi, E. Fly ash pollutants, treatment and recycling. In Pollutant Diseases, Remediation and Recycling; Lichtfouse, E., Schwarzbauer, J., Robert, D., Eds.; Springer International Publishing: Cham, Switzerland, 2013; Volume 4, pp. 103-213. 